\title{
Platelet counts during normal pregnancy
}

\author{
S. A. SEJENY, R. D. EASTHAM, AND S. R. BAKER \\ From the Department of Pathology, Frenchay Hospital, Bristol BS16 ILE
}

SYNOPSIS Eleven reports of platelet counts were found in the literature which reported a progressive increase, no change, or a progressive fall during pregnancy. The counts had been made using venous or capillary blood, with either simple dilution or red cell lysis prior to enumeration in a haemocytometer, with or without phase-contrast microscopy. It was therefore decided to examine whole blood platelet counts taken during normal pregnancy. Results from 405 venous blood samples, using an $\underset{\infty}{N}$ electronic platelet counter, confirmed the finding of a significant progressive fall in platelet counts $\vec{\circ}$ during normal pregnancy, the lowest counts falling in some women outside the recognized normal $\dot{\infty}$ range of values.

In a survey of the literature, there were three reports of an increase in platelet counts during pregnancy (Benhamou and Nouchy, 1932; Mor et al, 1960; Rebaudi, 1907). Five groups of workers reported that there was no significant change in the platelet count during pregnancy (Bland et al, 1930; Fresh et al, 1956; Kennan and Bell, 1957; Ratnoff et al, 1954; Todd et al, 1965). By way of contrast, there were three reports of a progressive fall in platelet counts during pregnancy (Bonnar et al, 1969; Shaper et al, 1968; Ward and MacArthur, 1948). There was great variation in the method of blood sampling and platelet counting, and the numbers of counts or patients studied were not large in 10 of these reports.

Following the acquisition of a Coulter Thrombocounter, it was felt that it would be valuable to examine blood counts taken from normal women during their routine attendance at local antenatal clinics, and a total of 405 blood samples were examined.

\section{Methods}

Platelet counts were carried out on $\mathbf{4 0 5}$ venous blood samples from normal pregnant women sent from local health centres for routine haematological investigation, using a Coulter Thrombocounter. Red-cell-poor dilutions of platelet suspensions for counting were prepared by a modification of a simple sedimentation method (Eastham, 1965); $0.2 \mathrm{ml}$ whole blood mixed with $1.8 \mathrm{ml}$ Isoton

Received for publication 21 April 1975. solution in $75 \times 10 \mathrm{~mm}$ siliconed tubes were stood $\stackrel{0}{\circ}$ for 1 hour, then $0.1 \mathrm{ml}$ of the red-cell-poor super- $\Phi$ natant was added to $10 \mathrm{ml}$ Isoton, mixed, and counted $\overrightarrow{0}$ in duplicate by means of the Coulter Thromb 8 or counter. Twenty replicate dilutions and counses on a sample of blood gave a mean whole blogd platelet count of $167 \times 10^{9}$ per litre with a ceefficient of variation of $2 \cdot 3 \%$.

\section{Results}

The results of platelet counts made on blood samples 3 taken during the three trimesters of pregnancy are shown in table $I$. There is a significant fall in whole? blood platelet counts during pregnancy, and

\begin{tabular}{|c|c|c|c|c|c|}
\hline $\begin{array}{l}\text { Trimester } \\
\text { of } \\
\text { Pregnancy }\end{array}$ & No. & $\begin{array}{l}\text { Mean } \\
\text { Platelet } \\
\text { Count }+ \\
10 \% \text { litre }\end{array}$ & $S D$ & Highest & Lowest \\
\hline $\begin{array}{l}\text { First } \\
\text { Second } \\
\text { Third }\end{array}$ & $\begin{array}{l}100 \\
101 \\
204\end{array}$ & $\begin{array}{l}210 \cdot 4 \\
203 \cdot 3 \\
183 \cdot 9\end{array}$ & $\begin{array}{l}52 \cdot 3 \\
45 \cdot 8 \\
50 \cdot 3\end{array}$ & $\begin{array}{l}383 \cdot 0 \\
361 \cdot 0 \\
324 \cdot 0\end{array}$ & $\begin{array}{r}137.0 \\
96.0 \\
75.0\end{array}$ \\
\hline
\end{tabular}

Table I Platelet counts during the three trimesters of pregnancy

\begin{tabular}{llll}
\hline Comparison & $t$ & Significance \\
\hline 1st $v$ 2nd & 1.06 & P $>0.05$ \\
1st $v$ 3rd & 4.21 & P $<0.001$ \\
2nd $v$ 3rd & 3.32 & P $<0.001$ & \\
\hline
\end{tabular}

Table II Using Student's t test a comparison of the results from three trimesters of pregnancy 
especially during the second and third trimesters (table II).

\section{Discussion}

Comparison of mean values of platelet counts obtained during normal pregnancy revealed a non significant decrease from the first to second trimesters, and a significant decrease from the second to third trimesters.

From 1907, 11 reports of platelet counts during pregnancy were noted. A variety of methods was used, including the use of either venous or capillary blood, simple dilution of blood or red cell lysis prior to enumeration in haemocytometers. Microscopy was used with or without the aid of phase contrast equipment.

Mor and his colleagues (1960) studied the largest number of patients and found a progressive increase in platelet counts during pregnancy. By contrast, Shaper et al (1968), reporting on the second largest number of patients, found a consistent fall in platelet counts during pregnancy. In the remaining nine studies, the number of pregnant women studied was small. In the present series $\mathbf{4 0 5}$ platelet counts were made. With the development of electronic particle-counting machines, platelet counts can now be made rapidly and with good replication. Samama et al (1974) compared counts made on diluted blood using microscopy with phase contrast with platelet counts made using a Coulter Fn counter on platelet-rich plasma (Bull et al, 1965) and whole blood platelet counts on the Technicon Autoanalyzer machine; they found that there was very close correlation of results by all three methods.

During normal pregnancy the plasma volume increases more than the red cell volume, and this present finding of a progressive decrease in the platelet count during pregnancy could reflect this relative increase in plasma volume, if platelet production remains fairly constant during pregnancy. This might be important in future considerations of the mechanism of control of the circulating platelet count in normal subjects. During long-term oral anticoagulant control it was found that, in the absence of complicating disease, the platelet count in an individual remained fairly constant about a mean value falling within the normal range (Eastham, 1966). Shaper et al (1968) found that the packed cell volume gave the indication of the degree of change taking place in the red cell mass and the plasma volume; they suggest that progressive falls in the platelet count from mid-term to labour indicate a direct relationship between the plasma volume changes and the corresponding platelet counts, plasma volume increasing more than red cell mass. The present findings suggest that in normal women with platelet counts at the lower end of the normal range, their platelet counts might fall below the accepted normal range during normal pregnancy. Whether such counts are of clinical significance is not known. Further studies are in progress to determine normal values throughout normal pregnancy.

\section{References}

*Benhamou, E. and Nouchy, A. (1932). Les plaquettes sanguines au cours de la menstruation, de la grossesse et des suites de couches. Gynéc. et Obstét., 25, 97-110.

*Bland, P. B., First, A., and Goldstein, L. (1930). The bloodplatelets in pregnancy and in the puerperium. Amer. J. Obstet. Gynec., 20, 165-173.

Bonnar, J., McNicol, G. P., and Douglas, A. S. (1969). Fibrinolytic enzyme system and pregnancy. Brit. med. J. 3, 387-389.

Bull, B. S., Schneiderman, M. A., and Brecher, G. (1965). Platelet counts with the Coulter counter. Amer. J. clin. Path., 44, 678-688.

Eastham, R. D. (1966). Adhesive platelets and myocardial infarction. Geriatrics, 21, 182-192.

Eastham, R.D. (1965). Simple method for separating platelets from red cells before enumeration with an electronic counter. J. clin. Path., 18, 248-249.

Fresh, J. W., Ferguson, J. H., and Lewis, J. H. (1956). Blood-clotting studies in parturient women and the newborn. Obstet. and Gynec., 7, 117-127.

Kennan, A. L. and Bell, W. N. (1957). Blood coagulation during normal pregnancy, labor, and the puerperium. Amer. J. Obstet. Gynec., 73, 57-64.

Mor, A., Yang, W., Schwarz, A., and Jones, W. C. (1960). Platelet counts in pregnancy and labor. Obstet. and Gynec., 16, 338-342.

Ratnoff, O. D., Colopy, J. E., and Pritchard, J. A. (1954). The blood-clotting mechanism during normal parturition. J. Lab. clin. Med., 44, 408-415.

Rebaudi, S. (1907). Blood platelets during pregnancy, labor, the puerperium and menstruation, and in the newborn. Amer.J. Obstet., 2, 475-481.

Samama, M., Capelle, C., and Beuzart, A. (1974). La numération des plaquettes. Path. et Biol., 22, 515-523.

Shaper, A. G., Kear, Jill, Macintosh, D. M., Kyober, J., and Njama, D. (1968). J. Obstet. Gynaec. Brit. Cwlth. 75, 433-441.

Todd, M. E., Thompson, J. H., Jr., Bowie, E. J. W., and Owen, C. A., Jr. (1965). Changes in blood coagulation during pregnancy. Mayo. Clin. Proc., 40, 370-383.

Ward, C. V. and MacArthur, J L. (1948). Blood platelet studies during pregnancy and the puerperium. Amer. $J$. Obstet. Gynaec., 55, 600-608.

*Quoted by Ward and MacArthur (1948). 